Dragutin Babić

DOI: https://dx.doi.org/10.21857/yk3jwhxjw9

Prethodno priopćenje

Rukopis prihvaćen za tisak: 21.10.2020.

\title{
OSNOVNO ŠKOLSTVO NACIONALNIH MANJINA U POŽEŠKO-SLAVONSKOJ ŽUPANIJI (FOKUS-GRUPA)
}

\section{Sažetak}

Uloga obrazovanja na svim razinama ima važan, a vjerojatno i presudan utjecaj - osim na obitelj - i na prijenos i daljnju izgradnju nacionalnog identiteta kako za većinsku nacionalnu zajednicu, tako i za nacionalne/etničke manjine. Stoga u ovom radu analiziramo osnovnoškolsko obrazovanje nacionalnih manjina u Požeško-slavonskoj županiji. Empirijsko istraživanje provedeno je metodom fokus-grupe na populaciji različitih aktera u obrazovnom sustavu i njegovoj političkoj i društvenoj logistici (učitelji, nastavnici, roditelji, političari). Nastava po modelu C u Požeško-slavonskoj županiji organizirana je na češkom, srpskom i slovačkom jeziku, pa su sudionici fokus-grupe bili i pripadnici tih nacionalnih zajednica. Cilj empirijskog istraživanja jest spoznati stavove i mišljenja aktera osnovnoškolskog obrazovanja nacionalnih manjina, posebno s obzirom na komunikaciju unutar nacionalne zajednice i s pripadnicima drugih nacionalnih zajednica. Opterećenje u komunikaciji svakako predstavljaju stereotipi, predrasude i stigme, koje su prisutne $u$ različitim vremenskim i prostornim ambijentima/lokacijama, a situacija se intenzivira u slučaju turbulentnih društvenih događaja, kakvi su bili naprimjer ratni sukobi devedesetih godina prošlog stoljeća na prostorima bivše Jugoslavije, uključujući Hrvatsku. Odnosi između pripadnika multinacionalnih lokalnih zajednica temelj su i glavni socijalni resurs integracije svih aktera u zajednicu, a time i u šire društvo. Obrazovanje nacionalnih manjina, u svojem normativnom i sadržajnom aspektu, čini važan segment očuvanja, prijenosa i socijalne konstrukcije identiteta nacionalnih manjina, pa se istraživanjem želi spoznati kakve su opservacije sudionika osnovnoškolskog obrazovanja nacionalnih manjina te čime su zadovoljni, a što bi se trebalo poboljšati. U procesima kontinuirane asimilacije te uslijed problema s integracijom i očuvanjem identiteta akteri navedenoga procesa, odnosno njihovo mišljenje i aktivnosti, važni su za aktualnu egzistenciju i perspektivu nacionalnih manjina čiji su pripadnici, a cilj je istraživanja bio supsumirati nalaze empirijskog istraživanja i istaknuti temeljne spoznaje, koji mogu potaknuti rješenja te problematike $u$ javnim politikama Republike Hrvatske.

Ključne riječi: nacionalne manjine; osnovnoškolsko obrazovanje; Požeškoslavonska županija; Česi; Srbi; Slovaci. 


\section{Uvod}

Nacionalne manjine u Hrvatskoj čine oko 7\% ukupne populacije, a njihov broj i udio, osim nekih izuzetaka, uglavnom se smanjuje od popisa do popisa stanovništva. Na tu izraženu tendenciju kontinuiranog smanjivanja nacionalnomanjinske populacije utječe više činilaca, od kojih su među važnijima: negativni prirodni prirast, demografsko starenje, asimilacija, iseljavanje i ratni sukobi devedesetih godina prošlog stoljeća. I osim otegotnih sociopolitičkih i drugih okolnosti koje utječu na te negativne tendencije, treba istaknuti i neke afirmativne, od kojih se mogu izdvojiti normativni aspekt rješenja nacionalnomanjinske problematike (Ustav Republike Hrvatske, Ustavni zakon o pravima nacionalnih manjina, Zakon o uporabi jezika i pisma nacionalnih manjina u Republici Hrvatskoj, Zakon o odgoju i obrazovanju na jeziku i pismu nacionalnih manjina), odmak od ratnih sukoba, tolerantnije sociopolitičko i sociopsihološko ozračje te ulazak Hrvatske u Europsku uniju. U procesu koji uključuje afirmaciju, očuvanje, prijenos i socijalnu konstrukciju nacionalnog identiteta jezik i njegovo korištenje imaju veliko značenje, kao i sekundarna socijalizacija, koja na sustavan način prenosi sadržaje kulture i baštine etničkih/nacionalnih manjina samim akterima iz tih zajednica. Stoga smo uzeli upravo segment osnovnoškolskog obrazovanja u korpusu nacionalnih manjina kao predložak analize kojom želimo spoznati kako sami pripadnici etničkih/nacionalnih manjina percipiraju navedena pitanja/probleme. U Hrvatskoj pripadnici nacionalnih manjina mogu u obrazovanju za nacionalne manjine koristiti jedan od tri postojeća modela takvog obrazovanja, A, B ili C. ${ }^{1}$ Odgoj i obrazovanje na jeziku i pismu nacionalnih manjina čini segment sustava odgoja i obrazovanja u Hrvatskoj usklađen s pedagoškim standardom Republike Hrvatske. Pripadnici nacionalnih manjina sami predlažu i odabiru model obrazovanja u skladu s postojećim zakonima i svojim mogućnostima za realizaciju programa, što često ovisi o njihovoj teritorijalnoj disperziji, broju i aktivnostima pripadnika u lokalnim i regionalnim zajednicama, kulturnoj i obrazovnoj tradiciji i najviše o njihovoj brojnosti. U svim predloženim modelima pripadnici nacionalnih manjina, uz nacionalne sadržaje, uče i hrvatski jezik, a broj sati ovisi o modelu nastave koji pohađaju. U modelu A cjelokupna nastava izvodi se na jeziku i pismu nacionalne manjine uz obvezno učenje hrvatskoga jezika u istom broju sati u kojem se uči jezik manjine. Taj model nastave provodi se u posebnim školskim ustanovama u kojima je cjelokupna nastava na jeziku pripadnika nacionalne manjine ili u posebnim odjelima u ustanovama s nastavom na hrvatskome jeziku. $\mathbf{U}$ modelu $\boldsymbol{B}$ primjenjuje se dvojezična nastava, $i$ to tako da se nastava prirodne grupe predmeta izvodi na hrvatskom jeziku, a društvene na jeziku pripadnika nacionalne manjine. Razlozi se tiču nacionalnog identiteta manjinskih zajednica, koji je povezan s jezikom i uku-

1 www.mzo, Obrazovanje nacionalnih manjina u RH. 
pnom kulturom i baštinom određene etničke ili nacionalne zajednice. I, nakraju, model $C$ podrazumijeva nastavu manjinskoga jezika i kulture kao dodatnu nastavu uz redovitu nastavu na hrvatskome jeziku. Na jeziku nacionalne/etničke manjine izvodi se nastava jezika i kulture nacionalne manjine u trajanju od dva do pet školskih sati tjedno, a obuhvaća učenje jezika i književnosti nacionalne manjine, geografije, povijesti te glazbene i likovne kulture/umjetnosti. Osim navedenih modela za nastavu nacionalnih manjina, postoje posebni oblici nastave kao što su seminari, zimske i ljetne škole i dopisno-konzultativna nastava. Nastavu nacionalnih manjina financira hrvatska država, a logističku podršku daju i države matice, što uključuje udžbenike, financijsku pomoć i posjete učenika tim zemljama. Fokus-grupa u Požeško-slavonskoj županiji s predstavnicima i sudionicima nacionalnomanjinskog obrazovanja oformljena je radi spoznavanja oblika, kvalitete i sadržaja obrazovanja za nacionalne/etničke manjine u toj županiji u funkciji edukacije mladih pripadnika tih zajednica i očuvanja njihova nacionalnog identiteta, što u krajnjoj liniji usporava asimilaciju i revitalizira same nacionalnomanjinske zajednice u Požeško-slavonskoj županiji.

\section{Sociodemografska i etnička 'slika' Požeško-slavonske županije}

Tablica 1. Etnička struktura stanovništva u Požeško-slavonskoj županiji (Popisi 1991., 2001. i 2011.)

\begin{tabular}{|l|l|l|l|l|l|l|}
\hline Nacionalnost & & 1991. & & 2001. & & 2011. \\
\hline & broj & $\%$ & broj & $\%$ & Broj & $\%$ \\
\hline Hrvati & 96.144 & 71,4 & 76.118 & 88,6 & 70.529 & 90,3 \\
\hline Albanci & 179 & 0,1 & 146 & 0,1 & 196 & 0,2 \\
\hline Austrijanci & 4 & 0,0 & 2 & 0,0 & 2 & 0,0 \\
\hline Musl./Bošnjaci & 200 & 0,1 & 48 & 0,0 & 48 & 0,0 \\
\hline Bugari & 2 & 0,0 & 2 & 0,0 & 3 & 0,0 \\
\hline Crnogorci & 87 & 0,0 & 22 & 0,0 & 14 & 0,0 \\
\hline Česi & 1.101 & 0,8 & 775 & 0,9 & 649 & 0,8 \\
\hline Grci & 3 & 0,0 & - & - & - & - \\
\hline Mađari & 388 & 0,2 & 221 & 0,2 & 164 & 0,2 \\
\hline Makedonci & 136 & 0,1 & 60 & 0,0 & 55 & 0,0 \\
\hline Nijemci & 107 & 0,0 & 78 & 0,0 & 43 & 0,0 \\
\hline Poljaci & 22 & 0,0 & 10 & 0,0 & 9 & 0,0 \\
\hline Romi & 7 & 0,0 & 7 & 0,0 & 13 & 0,0 \\
\hline Rumunji & 1 & 0,0 & 3 & 0,0 & 4 & 0,0 \\
\hline Rusi & 14 & 0,0 & 9 & 0,0 & 7 & 0,0 \\
\hline
\end{tabular}




\begin{tabular}{|l|l|l|l|l|l|l|}
\hline Rusini & 13 & 0,0 & 12 & 0,0 & 9 & 0,0 \\
\hline Slovaci & 1.324 & 0,9 & 120 & 0,1 & 95 & 0,1 \\
\hline Slovenci & 159 & 0,1 & 59 & 0,0 & 35 & 0,0 \\
\hline Srbi & 25.808 & 19,8 & 5.616 & 6,5 & 4.680 & 6,0 \\
\hline Talijani & 901 & 0,6 & 788 & 0,9 & 592 & 0,7 \\
\hline Turci & 4 & 0,0 & - & - & - & - \\
\hline Ukrajinci & 30 & 0,0 & 23 & 0,0 & 15 & 0,0 \\
\hline Vlasi & - & - & - & - & - & - \\
\hline Židovi & 3 & 0,0 & 1 & 0,0 & 1 & 0,0 \\
\hline Ostale narodnosti & 49 & 0,0 & 88 & 0,1 & 61 & 0,0 \\
\hline Nacionalno neopredijeljeni & 1.903 & 1,4 & 1.337 & 1,5 & 674 & 0,8 \\
\hline Jugoslaveni & 3.533 & 2,6 & - & - & - & - \\
\hline Regionalna pripadnost & 116 & 0,0 & 3 & 0,0 & 26 & 0,0 \\
\hline Nepoznato & 2.310 & 1,7 & 286 & 0,3 & 110 & 0,1 \\
\hline Ukupno & $\mathbf{1 3 4 . 5 4 8}$ & $\mathbf{1 0 0 , 0}$ & $\mathbf{8 5 . 8 3 1}$ & $\mathbf{1 0 0 , 0}$ & $\mathbf{7 8 . 0 3 4}$ & $\mathbf{1 0 0 , 0}$ \\
\hline
\end{tabular}

Izvori: Popis stanovništva 1991., Dokumentacija 881, Zagreb: Državni zavod za statistiku, 1992; Popis stanovništva 2001., Državni zavod za statistiku, 2002. Popis stanovništva 2011., Zagreb: www. Državni zavod za statistiku, 2013.

U sastavu Požeško-slavonske županije nalazi se pet gradova i pet općina. Gradovi su Požega, Pleternica, Pakrac, Lipik, Kutjevo, dok su općine Brestovac, Čaglin, Jakšić, Kaptol, Velika. Etnička struktura županije, s nekim specifičnostima, korespondentna je s ostalim slavonskim županijama (Virovitičko-podravska, Osječko-baranjska, Brodskoposavska, Vukovarsko-srijemska), pa i s Hrvatskom u cjelini. U njoj su zastupljene gotovo sve etničke/nacionalne manjine, a nakon 90-ih godina 20. stoljeća, tranzicije iz socijalističkog društvenog poretka u tržišno gospodarstvo i politički pluralizam, uz ratni raspad bivše jugoslavenske države, znatno su se promijenili sociopolitički status i neka sociodemografska obilježja nekolicine njih, posebno srpske nacionalne zajednice. Usporedba tri zadnja popisa stanovništva, od kojih je onaj iz 1991. proveden neposredno prije početka ratnih sukoba i disolucije bivše države, pokazuje da je posljedica nacionalne homogenizacije koja se dogodila u Požeško-slavonskoj županiji i u Hrvatskoj u cjelini porast broja i udjela etničkih Hrvata u ukupnoj populaciji. Tako je udio Hrvata u dva međupopisna razdoblja (1991. - 2001.) i (2001. - 2011.) porastao gotovo $20 \%$, a županija je postala izrazito homogena u svojem nacionalnom sastavu. Brojčano, dogodio se pad etničkih Hrvata, no to je objašnjivo pripajanjem bivše Općine Našice Osječko-baranjskoj županiji u posljednja dva popisa stanovništva, što se posebno reflektiralo na dvije nacionalne zajednice i njihov broj i udio u županiji - na 
Hrvate i Slovake. Najveći pad u navedenim međupopisnim razdobljima, posebno u prvom (1991. - 2001.), dogodio se u korpusu srpske nacionalne zajednice, koja je promijenila normativnu, a onda i zbiljsku poziciju prelaskom u poziciju nacionalne manjine. Udio Srba u popisu 1991. godine bio je značajan (19,8\%), da bi se u posljednjem popisu 2011. godine sveo na trećinu, što iznosi svega $6 \%$ udjela u ukupnoj populaciji Požeško-slavonske županije. Na prostoru županije, najprije u statusu izbjeglica, a kasnije u statusu hrvatskih državljana, registrirani su Hrvati iz Bosne i Hercegovine, uz manji broj i udio populacije koja nije dio hrvatskog etničkog korpusa. Uz značajno zastupljene Srbe, u županiji su još donekle prisutniji Česi i Talijani, a u popisu 1991. godine i Slovaci. Većina, kako 'starih' tako i 'novih' nacionalnih manjina², uz kontinuiranu asimilaciju, iseljavanje i ratne razloge, smanjila je svoj broj i udio u ukupnoj županijskoj populaciji. Albanska nacionalna manjina bilježi mali porast broja i udjela svojih pripadnika, što je uglavnom karakteristično i za Hrvatsku u cjelini, a objašnjivo je natalitetom većim od prosjeka, unutargrupnom kohezijom i obiteljskim sudjelovanjem $u$ specifičnim zanatima te njihovim prijenosom na mlađe pripadnike zajednice (pekari, slastičari, zlatari). S obzirom na dominaciju etnocentrizma i nacionalnog homogeniziranja koji su se dogodili, sa svakim popisom sve je manji broj i udio nacionalno neopredijeljenih, dok Jugoslaveni više nisu popisna kategorija. I uz postojanje i političkog aktivizma regionalnih stranaka, regionalna pripadnost nije značajnije zastupljena $u$ izjašnjavanju stanovnika županije.

\section{Multikulturalno/interkulturalno obrazovanje: problemi, aktualna i moguća rješenja}

Obrazovanje učenika, ali i ostalih građana u različitim oblicima, ima posebnu težinu u multietničkim/multinacionalnim društvima, a takav je i slučaj obrazovanja u Hrvatskoj. Hrvatska baštini etnički oblik nacije, za koji je karakteristično da nacija nije analogna državi i njezinim granicama, a većina etničkih/nacionalnih zajednica u državi zahtijeva politički legitimitet i sudjelovanje u vlasti na temelju te kolektivne pripadnosti. U obrazovanju se to reflektira u sferi učenja jezika i kulture svake od tih manjinskih zajednica, što pridonosi promicanju, kreiranju i očuvanju nacionalnih identiteta. Multikulturalizam i interkulturalizam nazivi su za politički koncept uređenja međunacionalnih odnosa i za teorijske pristupe $u$ analizi tih relacija i značenja za društvo $u$ cjelini te posljedično sve grupe i pojedince. Društva i države (post)modernog vremena imaju u svojem sastavu više etničkih/nacionalnih zajednica. Temeljni su razlog, kako kroz povijest tih društava tako još više u novijem vremenu, migracije stanovništva

2 Pod 'starim' nacionalnim manjinama ovdje se podrazumijevaju one zajednice koje su takav status ('narodnosti') imale u socijalističkom poretku i bivšoj državi, dok su 'nove' one koje su nastale od bivših konstitutivnih naroda SFRJ. 
uslijed različitih dobrovoljnih i nedobrovoljnih uzroka (poboljšanje statusa, traženje posla, ratovi, revolucije, epidemije i sl.). Svi navedeni procesi različito se interpretiraju, kako u kolektivnoj memoriji tako i kod pojedinih autora, ovisno, među ostalim činiocima, i o njihovim (sub)identitetskim obilježjima, uključujući i odnos prema naciji i nacionalnom. Stoga je u (post)moderno doba, kako ističe Sh. Sand, za percepciju i promociju homogenog kolektiva nuždan dugi narativ koji bi trebao sugerirati vremensku i prostornu vezu između očeva i 'predaka', što nužno vodi u redukcionizam povijesnih zbivanja i nameće pojednostavnjena stajališta te često proturječna povijesna zbivanja i njihove interpretacije (Sand, 2012). Kako to nije moguće potpuno postići, posebno u društvima s dominantno etničkim konceptom nacije (istočnoeuropska društva, uključujući hrvatsko), rješenja u uređenju međunacionalnih odnosa, a onda i u obrazovnom sustavu kao jednom od nekoliko najvažnijih uporišta/izvorišta nacionalnog identiteta, moguća su uz uvažavanje koegzistencije različitih kultura, koje se sve više prožimaju, ali svaka nacija zadržava svoj donekle drugačiji okvir. Problem koegzistencije više nacionalnih identiteta $u$ takvim je društvima u osiguranju društvene kohezije, kojoj mitovi, simboli, uspomene i ceremonije daju osnovu za integraciju i političku akciju, a heterogeni etnički/nacionalni sastav pritom nužno 'proizvodi' konflikt (Smith, 1996/1997). To je itekako evidentno na primjeru novonastalih država bivše Jugoslavije, uključujući Hrvatsku, gdje se upravo nameće potreba institucionalne regulacije navedene situacije i osiguranja prava svih etničkih/nacionalnih zajednica. $S$ obzirom na razliku između političkog (građanskog) modela nacije (Francuska, SAD i druga zapadna društva) i onog etničkog, u kojemu se nacija ne podudara s državom, prisutni su i različiti pristupi u interpretaciji, a onda i u operacionalizaciji tih modela. Na razini političkog uređenja međunacionalnih odnosa i reguliranja odnosa između različitih kultura, multikulturalizam je potekao iz Kanade, gdje je nastao kao širenje prijašnje zamisli o bikulturalizmu, 'dvokulturnosti' Anglokanađana i Frankokanađana (Heršak, 1998). Osim dvojezičnosti, taj program imao je za cilj očuvanje i promicanje kanadske baštine, ali tako da se očuvaju njezine različite etničke sastavnice. Vremenski nešto kasnije, Australija i neke europske zemlje prihvatile su politiku multikulturalizma. Kao glavni razlog koncepta multikulturalizma, koji naglašava različitosti kultura u društvu, navodi se imigracija (Abercrombie; Nicholas; Hill; Stephen; Turner; S. Bryan, 2008). Iako neki važni politički akteri suvremenog svijeta (Angela Merkel) najavljuju kraj multikulturalizma ${ }^{3}$, problem nije tako jednostavan ni jednoznačan (Mesić, 2012). Kako o tome piše M. Mesić, i uz slabljenje popularnosti termina multikulturalizam, (ne)priznavanja kulturnih različitosti, njihovo uređivanje još će dugo pred-

\footnotetext{
Njemačka kancelarka A. Merkel najavila je kraj multikulturalizma i u više navrata elaborirala navedenu tezu. Referirala se pritom na neuspjeh integracije, što - prema njezinu mišljenju - vodi stvaranju izoliranih 'otoka' migranata u odnosu na ostalo (većinsko) društvo. Doseljenici bi trebali prihvatiti njemačke vrijednosti i poštivati njemačke zakone.
} 
stavljati izazov za multinacionalna društva, kakva čine veliku većinu u svjetskim razmjerima (Mesić, 2012). Slično je i u Hrvatskoj, u kojoj različite etničke/nacionalne zajednice nastoje očuvati i dalje afirmirati sustav vrijednosti koji čini njihov nacionalni identitet. Sustav školstva ima pritom posebno važnu ulogu, jer se tu na institucionalno organiziran način obrazuje mladi naraštaj tih zajednica, koji bi u skoroj budućnosti trebao biti nositelj aktivnosti usmjerenih na očuvanje zajednice, njihovu integraciju $u$ hrvatsko društvo i sprečavanje ili barem usporavanje asimilacije njihovih pripadnika u većinsku nacionalnu zajednicu. Multikulturalno obrazovanje ima više ciljeva, a W. Feinberg navodi tri: informiranje učenika o kulturnoj raznovrsnosti, poštivanje života i običaja drugih grupa i poticanje pripadnika drugih grupa da se ponose vlastitim kulturnim naslijeđem (Feinberg, 2012). U okviru takvih interpretacija nacionalne zajednice, bilo one dominantne ili one $u$ statusu manjinskih, trebale bi imati slobodu kreiranja i razvoja vlastitog obrazovnog sustava, usporedno s građanskim obrazovanjem (Tamir, 2002). Hrvatski obrazovni sustav s ponuđenim modelima korespondira $\mathrm{s}$ navedenim sugestijama, uz uvažavanje hrvatskih specifičnosti. Za razliku od multikulturalizma, interkulturalizam označava međusobno povezivanje raznih kultura $\mathrm{u}$ društvu te međudjelovanja i međusobna prožimanja tih kultura, koje u konačnici čine temeljnu nacionalnu kulturu (Heršak, 1998). Iz toga pristupa proizlazi i novi koncept obrazovanja, koji uvažava kulturne razlike učenika vodeći računa i o drugim razlikama među njima. Pritom se u interkulturnom obrazovanju uče različiti sadržaji iz života etničkih skupina, a nastava se organizira za cjelokupnu školsku populaciju, a ne samo za manjinsku ili doseljeničku (Heršak, 1998: 85). Hrvatsko osnovnoškolsko (i srednjoškolsko) obrazovanje ima elemente multikulturalnog pristupa, najviše u modelu A, dok model B, a posebno model C, imaju više značajke interkulturalnog pristupa, koji preferira prožimanje edukativnih i kulturnih sadržaja. $S$ obzirom na dugotrajno povijesno naslijeđe, višestoljetni suživot i potrebu integracije svih pripadnika hrvatskog društva s posebnim izazovom u poslijeratnom razdoblju, interkulturalizam se u Hrvatskoj nameće kao društveno poželjna paradigma uređivanja međunacionalnih odnosa. Kada se analiziraju koncepti i pristupi međunacionalnim odnosima, a onda i obrazovanju, dva su dominantna, liberalni i multikulturni, koji su primjereni političkom (građanskom), odnosno etničkom obliku nacije. Tako B. Barry kritizira multikulturalni pristup naglašavajući da je sustav liberalnih zakona koji se referira na građanina stvorio manje problema u uređenju društva od 'politike različitosti', prema njemu, sklone proizvodnji konflikta (Barry, 2006). Njegov pristup, kao i pristup i drugih autora sličnih njemu, povezan je s političkim (građanskim) oblikom nacije. Za razliku od njega, predstavnik multikulturalističke paradigme W. Kymlicka ističe da se suvremena društva sve više suočavaju s potrebom i zahtjevom za manjinskim priznanjem i uvažavanjem kulturnoidentitetskih razlika (Kymlicka, 2003). Iako liberalni koncept uređenja društva u ambijentu političkog (građanskog) modela nacije tretira sve građa- 
ne jednako, neovisno o njihovim kolektivnim (sub)identitetima (nacionalni, vjerski, jezični i drugi), sve to, kako ističe Ch. Taylor, pati od prenapregnutosti (Taylor, 1996/1997). Država ipak i ovdje ima svoju središnju kulturnu jezgru, a napetosti koje proizlaze iz etničke i druge šarolikosti treba nekako riješiti. Ili, kako o tome piše V. Katunarić, nacionalna država na Zapadu ima izdvojenu etničku jezgru, koja reprezentira društvenu većinu, pa se i tu zna tko je bliže, a tko dalje od države (Katunarić, 1991). Iako su suvremena društva više pluralistična, uz veći opseg ljudskih i manjinskih prava koje akteri koriste, to nije umanjilo značenje nacije i nacionalnog identiteta već naprotiv - identifikacija s nacijom povećava se iz više razloga, od kojih R. Rizman navodi osjećaj sigurnosti u društvima sve većeg rizika, neizvjesnosti i straha pa do modusa transcendiranja naše fizičke konačnosti i povezivanja s pretcima i potomcima na tom svojevrsnom međugeneracijskom projektu (Rizman, 2014). U Hrvatskoj je sve navedeno još pojačano uslijed traumatičnih i teških posljedica ratnih sukoba devedesetih godina prošlog stoljeća, naglašenog etnocentrizma i etnonacionalne interpretacije svih aspekata prošlosti, svakodnevne aktualne zbilje kao i projekcija perspektive. U školskom sustavu kao temeljni problem nameće se kako izaći iz ovih socijalnih i sociopsiholoških obrazaca i uvažiti činjenicu etničke/nacionalne diverzificiranosti i potrebe mnogobrojnih etničkih/nacionalnih zajednica u sferi kulture i očuvanja njihovih kolektivnih identiteta, posebno etničkih/nacionalnih. Izazov pred kojim se nalazi hrvatsko društvo i država u poslijeratnom i tranzicijskom razdoblju odnosi se na istovremeno razvijanje i jačanje hrvatskog nacionalnog identiteta, a uz to na promicanje dijaloga $\mathrm{i}$ tolerancije te kreiranje suradnje sa sličnim zajednicama u Hrvatskoj. U 'etničkim vremenima' (Kecmanović, 2001) to nije ni lak ni jednostavan zadatak za državnu vlast na svim razinama. Institucionalni je okvir nuždan, ali ne i dovoljan uvjet za rješavanje te situacije, paradigmatske (na različite načine) za sva multikulturalna društva. Različitost etničkih/nacionalnih tradicija, odnos prema državi i poretku, njihova česta promjena na ovim prostorima, posebno ratni sukobi 90-ih godina prošlog stoljeća i ratni raspad SFRJ, dodatno su traumatizirali i opteretili javnu scenu, posebno u sferi međunacionalnih odnosa. Iako su izazovi prisutni u slučaju svih nacionalnih manjina, najveći su u slučaju srpske nacionalne zajednice, kojoj je promijenjen politički status u Hrvatskoj, a znatan dio pripadnika te nacionalne zajednice sudjelovao je u pobuni protiv osamostaljenja Republike Hrvatske, uz aktivnu podršku JNA. No isto tako, uz lojalnost hrvatskoj državi u njezinu konstituiranju u samostalni entitet, nemali dio Srba (prema procjeni, oko 10.000) sudjelovao je u njezinoj obrani. Najsloženiji prostor sa stajališta integracije različitih etničkih/nacionalnih zajednica, s teškim ratnim traumama, svakako su hrvatsko Podunavlje i grad Vukovar, s djelomičnom segregacijom u slučaju tamošnjih Srba. Romska populacija nije problematična iz političkih ili ratnih razloga već zbog tradicionalnog, supkulturnog načina života, različitog u odnosu na ostale pripadnike hrvatskog društva, sa sporim promjenama, što sve otežava njihovo 
uključivanje u društvo. Problemi se mogu i trebaju rješavati obostrano, aktivnijim sudjelovanjem pripadnika romske zajednice i afirmativnom politikom hrvatskih institucija u pojedinim segmentima društvenog života. Sljedeći izazov s kojim se susreću operativci i teoretičari u multikulturalnim društvima jest pitanje/problem metodološkog nacionalizma. Je li moguće izaći iz državnog/nacionalnog motrišta, za koje U. Beck smatra da funkcionira kao svojevrsni limit sociološke percepcije (Mesić, 2007)? Nasuprot metodološkom nacionalizmu, metodološki kozmopolitizam transcendirao bi okvir nacije, pa ostaje pitanje je li to moguće. Pozivajući se na Sh. Sanda, to nije moguće bez ostatka. Kako taj autor navodi, teoretičar društva akumulira različite slojeve pamćenja prije nego što postane istraživač, pa je i sam znanstvenik kulturni proizvod prethodno usađenih memorija (Sand, 2012). I dalje, što bi to trebalo značiti u obrazovnom sustavu Hrvatske, u kojoj, osim etnički većinskih Hrvata, žive brojne etničke/nacionalne manjine, ukupno dvadeset i dvije, uz određeni postotak stanovnika koji se nacionalno ne izjašnjavaju? Potreba za kvalitetnim obrazovanjem uključuje praćenje tehnoloških dostignuća i spoznaja u različitim poljima znanosti i segmentima gospodarstva, ali i najboljih postignuća u sferi ljudskih, građanskih i manjinskih prava. Nacionalne zajednice, bez obzira na njihovu brojnost, žele očuvati nacionalni identitet, jezik, tradiciju, kulturu, a pretpostavka za to jest, uz primarnu socijalnu sferu, i sekundarna socijalizacija, čiji je najvažniji reprezentant obrazovni sustav. U Hrvatskoj se obrazovanje nacionalnih manjina provodi u različitim oblicima, od seminara preko ljetnih i zimskih škola do odgojno-obrazovnih institucija kao što su vrtići te osnovne i srednje škole, a za kadrove koji će obrazovati pripadnike nacionalnih manjina tu su i neke studijske grupe i katedre na fakultetima. Za istraživanje osnovnoškolskog obrazovanja, čime se u ovom radu bavimo, svakako su najvažniji modeli osnovnoškolskog obrazovanja oni pod nazivom A, B i C, a u ovom istraživanju na prostoru Požeškoslavonske županije analizira se model $C$, koji pohađaju pripadnici češke, srpske i slovačke nacionalne manjine.

\section{Empirijsko istraživanje (fokus-grupa)}

\subsection{Metodologija}

U sklopu istraživanja predviđenog za Hrvatsku u cjelini, u Požegi je 17. veljače 2018. održana fokus-grupa u Maloj vijećnici Županijske skupštine. Sudionici fokusgrupe bili su: Snježana Nitraj, OŠ Vilima Korajca, Kaptol, C-model, Česi, roditelj; Ana Marinac, OŠ Vilima Korajca, Kaptol, C-model, Česi, nastavnica; Gojko Nenadović, ing. zaštite na radu, potpredsjednik Vijeća Srpske nacionalne manjine grada Požege, vijećnik Županijske skupštine Požeško-slavonske županije, Požega; Mirsada Popović Damjanović, vijećnica grada Pakraca, roditelj (Srbi), Šeovica; Miroslav Grozdanić, dožupan Požeško-slavonske županije iz redova srpske zajednice, Lipik; Borka Teodorović, srpski 
jezik, pravoslavni vjeronauk, Okučani, Trojeglava, Dežanovac, živi u Pakracu; Pavel Treger, profesor, predsjednik Matice slovačke Jakšić; Lana Malina, učiteljica češkog jezika, Pakrac; Mirko Marković (istraživač); Dragutin Babić (voditelj, moderator). U okviru kvalitativnog pristupa empirijskom istraživanju, jedna od metoda jest fokus-grupa, s određenim prednostima i ograničenjima. Za fokus-grupu specifično je da se u samom istraživanju unutar nje događa interakcija između ispitanika koji su odabrani i relevantni za temu koja se istražuje (Skoko; Benković, 2009). Fokus-grupa slična je intervjuu, a za razliku od intervjua, $\mathrm{u}$ fokus-grupi moderator usmjerava razgovor na određene teme postavljajući potpitanja radi dobivanja što iscrpnijeg odgovora na postavljena pitanja. U komparaciji s anketnim istraživanjem, rezultati fokus-grupe, što je i njezino ograničenje, nisu reprezentativni za ciljanu populaciju i ne mogu se poopćiti onako kako se to čini u kvantitativnim istraživanjima (Skoko; Benković, 2009). Sudionici fokus-grupe poznaju problematiku, a u fokus-grupi sudjeluje $6-8$ osoba, pa se tu malu skupinu usredotoči na pitanja i što detaljniju raspravu o njima, uz mogućnost ponavljanja takvih razgovora (Abercrombie; Hill; Turner, 2008). Prednosti fokus-grupe dublje su i serioznije informacije koje se dobivaju tim postupkom, uz veću međusobnu povezanost i analizu uzroka i posljedica društvenih događanja. Funkcija moderatora jest postavljanje potpitanja radi što kvalitetnije spoznaje stavova i mišljenja sudionika te intenzivnijeg ulaska u bit problema koji se istražuje. Potencijalna opasnost krije se u konformizmu stavova ispitanika u odnosu na stavove ostalih članova grupe u istraživanju (Skoko; Benković, 2009). Pitanja u fokus-grupi polaze od šireg pristupa, a odnose se na to s kojim se problemima suočavaju akteri iz korpusa nacionalnih manjina, od suživota s ostalima, socijalne interakcije u lokalnim zajednicama, ostvarenja svojih prava i sudjelovanja u javnim poslovima u lokalnom i regionalnom okruženju. Slijede zatim pitanja o kvaliteti socijalne interakcije i komunikacije na mikrosocijalnoj razini, njihovim aktivnostima u udrugama (folklornim društvima i drugim sekcijama) i vijećima, gdje se okupljaju pripadnici pojedine nacionalne manjine. Nadalje, zanimalo nas je koliko su se sudionici fokus-grupe, njihova djeca, prijatelji, susjedi ili poznanici susretali s neprimjerenim postupcima u školi prema njima a koji su vezani za pohađanje manjinske nastave i/ili njihove nacionalnosti; zatim koji su sve motivi i razlozi pohađanja posebnog obrazovnog programa za pripadnike nacionalnih manjina u Požeško-slavonskoj županiji; koliko pripadnici nacionalnih manjina u toj županiji/ naselju govori jezikom svoje nacionalne manjine kod kuće; je li učenje materinskog (manjinskog) jezika u školi važno za očuvanje nacionalnomanjinskog identiteta; što sudionici fokus-grupe misle o sadašnjem planu i programu nastave materinskog (manjinskog) jezika i kulture i koliko su upoznati s izradom novog kurikuluma; koliko su učenici motivirani za nacionalnomanjinski program i ima li razlike u motivaciji i pohađanju tih programa između osnovnoškolaca i srednjoškolaca; koliko učenici nacionalnih manjina $\mathrm{u}$ županiji koriste jezik svoje nacionalne manjine u svakodnevnoj 
komunikaciji s vršnjacima i prijateljima, a koliko u komunikaciji s rodbinom. Na temelju provedenog empirijskog istraživanja, u radu će se analizirati dobiveni rezultati u suglasju s prikladnim teorijskim okvirom.

\subsection{Komunikacija: stereotipi, predrasude, stigme, suživot}

Za integraciju pripadnika u društvo i njihove međusobne odnose važna je uzajamna percepcija te 'slike u glavama' aktera (Roth, 2000), koje su važne za zajedništvo na politički definiranom teritoriju. Iako su stereotipi, predrasude i stigme neizostavni dio svakog društva, pitanje je koji je njihov intenziteta i frekvencija, što društva dijeli na ona u kojima su takvi sociopsihološki obrasci prisutni do podnošljivosti i ona u kojima različiti pojedinci i skupine, pa i s institucionalne razine, te obrasce perpetuiraju i instrumentaliziraju u funkciji očuvanja moći i vlasti te marginaliziraju i isključuju pripadnike nekih, uglavnom manjinskih, zajednica iz društva, s potencijalno i zbiljski konfliktnom situacijom u lokalnim zajednicama. Kakva je komunikacija i socijalna interakcija između pripadnika nacionalnih manjina u lokalnim zajednicama županije međusobno i s pripadnicima etnički hrvatske većine? Što o tome kažu sudionici fokusgrupe održane u Požegi? „Pripadnici Češke nacionalne manjine na kaptolačkom području susreću se uglavnom sa identičnim problemima kao i pripadnici većinskog hrvatskog naroda. Najveći problem Češke besede je nedostatak mladih ljudi u njihovoj upravnoj strukturi. (...) Što se tiče komunikacija i suradnje, ona je dobra, kako u odnosu između manjina, tako i u odnosu s većinskom hrvatskom nacijom." (Nastavnica, OŠ Kaptol, Česi) Česi su integrirani u hrvatsko društvo i odgovor spomenute sudionice je očekivan. Iako se Česi postupno asimiliraju, taj proces nije rapidan, a vrlo kvalitetna integracija pripadnika te nacionalne zajednice, na svim razinama, od normativne do funkcionalne, obilježje je kako Požeško-slavonske županije tako i Hrvatske u cjelini. „Na području županije moramo imati postotak da bi imali dožupana, Srbi su demografski devastirani, sve ih je manje, stariji su, bez reproduktivne perspektive. U narednom periodu nećemo imati taj postotak. U Požegi imamo u srpskoj populaciji 1 dijete rođeno na 50 umrlih. Srbi su sada nacionalna manjina... bili su konstitutivni narod. Teško je od tada ući u bilo koji sustav vlasti, školstvo se organizira za nacionalne manjine i Srbi tu koriste jedan od modela, ovisno koliko ih ima na jednom prostoru... Prijateljstva pojedinačno su čak vrlo dobra pa i odlična, ali odnos prema zajednici je drugačiji, tu je problem, Srbi su obilježeni... Prije tjedan dana su zapošljavali žene za kućnu njegu pa su po mjesnim odborima prikupljeni podaci o onima koji će se zaposliti, a to su oni blizu ili iz vladajuće stranke..." (potpredsjednik Vijeća Srpske nacionalne manjine grada Požege, vijećnik Županijske skupštine Požeško-slavonske županije, Požega). Pripadnik srpske nacionalne zajednice kao predstavnik te zajednice i sudionik politike na razini županije ima kritičkiju opservaciju međunacionalnih odnosa u županiji, posebno odnosa prema Srbima. Stigma te zajednice jest prisut- 
na, dok su pojedina prijateljstva i dobri susjedski odnosi pokazatelj da je suživot između pripadnika različitih nacionalnih zajednica prisutan, iako je na relaciji prema srpskoj zajednici znatnije narušen. To je često prisutno u međunacionalnim odnosima na lokalnoj razini. Odnosi između pojedinaca mogu biti prijateljski, ali ne mogu preformulirati 'zadane' odnose između zajednica, pa često postaju njihovom žrtvom (Vlaisavljević, 2018). „Situacija je puno bolja nego što je bila ranije (...) Svetosavska akademija, neugodnost, skinuta je slika Tuđmana, odmah je dignuta graja, Srbi skidaju Tuđmana, onda se odmah sve pretvara u incident, ispaštaju onda i oni koji tu nisu bili... odmah negativna konotacija." (dožupan Požeško-slavonske županije iz redova srpske zajednice, Lipik). Iz prethodnog iskaza primjećuje se pomak prema boljem ozračju u javnom prostoru i odnosu prema pripadnicima srpske nacionalne manjine. Odmak od ratnih vremena i povećanje tolerancije u društvu, afirmacija ustavnopravnih rješenja o nacionalnim manjinama i ulazak Hrvatske u Europsku uniju tome su pridonijeli. Odnos prema simbolima, događajima i osobama i dalje će, iako manje nego u nedavnoj prošlosti, izazivati prijepore i probleme u sferi međunacionalnih odnosa. „Danas je u Pakracu teško naći posao, a i ono što ima to je više izrabljivački... mladi sve više odlaze. Žene starije životne dobi koje su dobile otkaz idu u Njemačku i tamo rade sezonske poslove, neke dobiju posao i za stalno pa ostaju u Njemačkoj. Nas muči infrastruktura, ima dosta neriješenih problema vezanih za nastavu djece srpske nacionalnosti. Ne mogu sudjelovati na nekim aktivnostima, nema prijevoza." (vijećnica grada Pakraca, roditelj, Srbi, Šeovica). Iako se referira na neke specifične probleme u školskom sustavu i njegovoj organizaciji, sudionica istraživanja navodi tipične egzistencijalne probleme znakovite za sve građane, koji iz sociodemografskih razloga (starije stanovništvo) $i$ onih generiranih iz ratnih zbivanja više pogađaju srpsku zajednicu. Slijede slična razmišljanja: „Jedan od problema s kojim se posebno susreće srpska zajednica je staračko stanovništvo... vrlo malo je mladih po naseljima, srpska sela, tamo gdje su Srbi bili u većini, se gase ili su već ugašena. Cestovni pravci su problematični, nema asfalta, makadam je dosta loš... Struja, slab odvod, autobusne linije nema, poseban problem postoji kod prevoza srednjoškolske djece do škole. Problem na liniji Požega, Pakrac, Lipik... sa županijskim centrom nemaju veze... zapošljavanje vrlo slabo, puno žena je zaposleno u trgovačkom sektoru... Dio ljudi se boji... kod Džakule su došli u Popisu stanovništva, sugeriraju mu da se on ne mora izjasniti kao Srbin... bojazan, državni pritisak, needucirani pojedinci. (...) Udruga branitelja protiv liturgije, bio je kulturno-umjetnički program na Trgu u Požegi, branitelji su bili protiv.“ (dožupan Požeško-slavonske županije iz redova srpske zajednice, Lipik). Češka nacionalna manjina ima više unutargrupnih problema nego problema sa širim društvom. Ističe se nedovoljna uključenost mladih pripadnika te zajednice u aktivnosti na očuvanju, prijenosu i daljnjoj izgradnji nacionalnog identiteta. „Pripadnici češke nacionalne manjine u Požeško-slavonskoj županiji se suočavaju s tim da sve više mlade generacije gubi 
interes za uključivanjem u život nacionalne manjine. Sve je češća pojava da su aktivni članovi Čeških beseda stara ili srednja populacija. (...) Suradnja s pripadnicima ostalih nacionalnih manjina je dobra, isto kao i s pripadnicima većinske hrvatske nacije. (...) Da, aktivna sam članica Češke besede Lipovec (Ljudevit Selo) u kojoj vodim folklornu grupu učenika nižih razreda osnovne škole i glumim u dramskoj sekciji Besede." (učiteljica češkog jezika, Pakrac). Aktivnosti sudionika/sudionica fokus-grupe, osim u nastavi, prisutne su u folkloru te umjetničkim i drugim kulturnim događanjima, što je u simboličkoj sferi najvažnije za očuvanje nacionalnog identiteta. „Koliko sam ja upoznata naša Češka beseda kao glavna predstavnica češke manjine kod nas veoma dobro surađuje kako sa drugim nacionalnim manjinama... prvenstveno na kulturnom području (međusobni posjeti na kulturno umjetničkim događanjima) ali dobra suradnja je sa lokalnom zajednicom koja je pružila veliku pomoć pri organizaciji nedavnih žetvenih svečanosti... Moja djeca idu na folkor Češke besede... ja nisam previše aktivna ali uskočim po potrebi, kada treba sastaviti neku konferansu ili voditi program (kao npr. prije nekoliko dana prigodom 95. godišnjice osnutka Češke besede Kaptol)." (učiteljica, roditelj, Česi, OŠ Vilima Korajca, Kaptol). Sudionik iz slovačke zajednice o odnosu pripadnika etničke većine prema njima navodi: „U Jakšiću nastupam na svim društvenim događanjima. Svećenik nas pozove da Slovaci dođu u narodnim nošnjama. Malo se promijenio odnos prema nama... Opterećenje nacionalnih manjina svugdje postoji, prisutno je u različitim situacijama i društvima." (profesor, predsjednik Matice slovačke Jakšić). Sudionici fokus-grupe i njihovi bližnji (prijatelji, poznanici, susjedi) susreću se sa stereotipima, predrasudama i stigmama u svojim naseljima i bližoj socijalnoj okolini. Pozicija nacionalnih manjina pritom je različita, a - zbog ratnih razloga - u najnepovoljnijem je položaju srpska nacionalna manjina. Kako te probleme percipiraju akteri ovoga istraživanja? Odgovori sudionika na pitanja o percepciji pripadnika njihove nacionalne zajednice $\mathrm{u}$ županiji su različiti, uglavnom $\mathrm{u}$ korelaciji s pozicijom i 'slikama' njihove nacionalne manjine u mikrosocijalnoj okolini i u širem društvu. Bilo je očekivano da će Česi uglavnom isticati kvalitetnu integraciju u naseljima u kojima žive kao i u hrvatsko društvo u cjelini. To ne znači da u socijalnoj interakciji pripadnika te nacionalne zajednice s ostalima, pa i etnički većinskim Hrvatima, nema nikakvih problema. Predrasude i stereotipi su prisutni, ali uglavnom u benignoj varijanti, koja na razini socijalnih kontakata ljudima ne pravi veće probleme. Ističe se dobra suradnja, kako u odnosu na Hrvate, tako is drugim nacionalnim manjinama na prostoru županije. Kao veći problem Česi ističu slabiju aktivnost mladih članova zajednice i njihov manji interes za javno djelovanje, što svakako otežava sve aktivnosti na očuvanju nacionalnog identiteta te zajednice. Srpska populacija u poslijeratnom razdoblju demografski je devastirana, s uglavnom starijim kontingentima stanovništva u ukupnoj populaciji. Iako na razini pojedinačnih odnosa s većinskim stanovništvom ima primjera kvalitetnih susjedskih i prijateljskih odnosa, percepcija 
srpske zajednice $u$ cjelini izrazito je opterećena ratnim događanjima. Kao i u svim sličnim situacijama, posebno u slučaju etničkog oblika nacije i društava sa znatnom prisutnošću kolektivističkih obrazaca ponašanja i djelovanja, takve se percepcije teško i sporo mijenjaju. Pritom je problem u parazitiranju aktera iz sfere politike na tim vrijednosnim obilježjima te po potrebi intenziviranju istih. Postupnim uvođenjem, prije svega u obrazovni sustav, civilizacijskih normi koje se temelje na punom poštovanju svih različitosti, koje čine ukupan identitet pojedinaca, moguć je iskorak prema tolerantnijem društvu. No i tada se, s promjenom lica kulture (Katunarić, 2007), mijenjaju odnosi prema onima koji nisu dio dominantne grupe. Ili, kako taj autor ističe referirajući se na Wallersteina, kolektivni identiteti izvedeni su iz dinamike i međuodnosa svjetskoga gospodarstva te međunarodne i unutarnje politike. Univerzalno lice kulture pokazuje se u vremenima prosperiteta, a partikularno u kriznim godinama, što je najbolje vidljivo u odnosu prema stranim radnicima i izbjeglicama, a svakako i prema nacionalnim manjinama. Srbi ističu problem prijevoza, u selima nema asfalta, struje, prevladava staračko stanovništvo, a kod popisa stanovništva Srbi su pod pritiskom i sugestijama da se ne moraju izjašnjavati kao Srbi, što može pojačati etnomimikriju u toj zajednici. Sociopsihološki ambijent prožet je etnonacionalizmom, što se reflektira i na praktične aktivnosti i odnose u lokalnoj zajednici i šire. Slovaci ističu relativno afirmativan odnos prema njima, pa navode da ih sve više pozivaju na različite manifestacije uključujući i one koje organiziraju etnički Hrvati. No ipak, sudionik iz redova Slovaka konstatira ono što je prisutno gotovo svugdje, a to je da su pripadnici manjine barem donekle obilježeni i pod pritiskom.

\subsection{Obrazovanje nacionalnih manjina: prednosti i nedostaci postojećeg sustava i školske prakse}

Hrvatska ima na normativnoj razini uređen sustav nacionalnomanjinskog obrazovanja s diverzificiranim ponudama, u obliku A, B i C modela. Pohađanje pojedinih od tih modela u zavisnosti je od teritorijalne raširenosti nacionalnih manjina, tradicije obrazovanja za te manjine, njihove organiziranosti i drugih činilaca. Veći interes prisutan je za osnovnoškolsko obrazovanje, dok se u srednjoj školi, najviše zbog drugih preferencija, od školskih do izvanškolskih, smanjuje broj učenika koji pohađaju obrazovanje za nacionalne manjine. Iako je na normativnoj razini ponuđeno dovoljno različitih modela obrazovanja za nacionalne manjine, u javnosti je često pitanje koje se odnosi na sadržaje tih oblika obrazovanja, kadrovsku problematiku, infrastrukturu i druge dimenzije iz tog područja. Koliko su sudionici fokus-grupe zadovoljni ponuđenim modelima i posebno njihovom realizacijom u Požeško-slavonskoj županiji? Što o tome kaže roditelj iz češke nacionalne zajednice? „Kod nas u školi je organizirana nastava češkog jezika i kulture po modelu $C$ koju trenutno pohađa velik broj učenika (od prvog do osmog razreda u dvije skupine: Prvi stupanj 
- razredna nastava - učiteljica Ana Marinac (oko 14 učenika), drugi stupanj - predmetna nastava - učiteljica Snježana Nitraj (oko 13 učenika). Glavni motivi zašto učenici pohađaju tu nastavu su... jer ju pohađaju i njihovi prijatelji i znaju da je to jedan opušteniji pristup nastavi za koji će ipak dobiti solidnu ocjenu. Motivacija su i izleti koji se povremeno organiziraju uglavnom od strane lokalne Češke besede, sudjelovanje npr. na 'Našem jaru' (nešto kao lidrano što podrazumijeva kako nastup, tako i neku vrstu izleta, večere nakon nastupa, drugim riječima - ugodnog druženja ali i kulturnog obogaćivanja i stjecanja socijalizacijskih vještina). Zbog gore navedenih razloga većina učenika pohađa nastavu češkog jezika i kulture modela $C$, mali broj njih ima češke korijene, no ima i takvih koji imaju rodbinu u Češkoj te im češki jezik kao takav dobro dođe i mogu ga praktično primijeniti. Kao npr. moja djeca koja u Češkoj imaju dosta rodbine (djeda, baku, tetku, bratiće, sestrične itd.“ (učiteljica, roditelj, Česi, OŠ Vilima Korajca, Kaptol). Jezik je izrazito važan za očuvanje nacionalnog identiteta, a Česi, i ne samo oni, pohađaju nastavu u modelu $\mathrm{C}$ u županiji. Motivi su različiti, od nacionalne pripadnosti i emocionalne komponente pa do kolegijalnih i utilitarnih razloga, posebno kod onih koji nemaju češke 'korijene'. „Cmodel je $\mathrm{u}$ školi gdje predajem, $\mathrm{u}$ više škola prisutan. Malo je učenika, Okučani - 4 učenika, Pakrac - 14 učenika, Trojeglava - 1 učenik, Dežanovac -2 učenika. Imam malo đaka, teško je uskladiti raspored. Djeca nemaju prijevoz, pa smo se organizirali i vozili djecu. Prošle godine povodom dana grada Lipika, organiziran je i Dan nacionalnih manjina, Talijani, Česi..." (učiteljica, srpski jezik, pravoslavni vjeronauk, Okučani, Trojeglava, Dežanovac, živi u Pakracu). Problem učenja jezika i kulture u slučaju srpske nacionalne manjine svodi se na demografski problem, odnosno na mali broj učenika, što otežava organizaciju nastave. „Školski program je dobar za 1-8 razred, zadovoljavajući je, postoji nedostatak udžbenika. 1998. je štampan udžbenik, nikakvi udžbenici nisu nakon toga rađeni. Za pravoslavni vjeronauk knjige su iz Banja Luke. Knjigu iz 'Prirode' imam samo ja. Udžbenik mora biti važeći 4 godine. U razredu se nađu dijete iz prvog i ono iz osmog razreda, pa to zna biti i je problem. Problem prilagodbe... kadrovski problemi.“ (učiteljica, srpski jezik, pravoslavni vjeronauk, Okučani, Trojeglava, Dežanovac, živi u Pakracu). Navode se i drugi problemi u obrazovanju pripadnika srpske zajednice. Udžbenici su prema pedagoškim normativima zastarjeli ili ih u nekim predmetima nema, a navodi se i nedostatak kadrova. „Najveći motiv pohađanja učenika nastave češkog jezika je taj, što su njihovi roditelji pripadnici te nacionalne manjine. Postoje i drugi razlozi, kao npr.: dobra ocjena, manje zahtjevni programi, izleti i druženja. Komunikacija na češkom jeziku između članova obitelji je sve slabija. To prakticira više starija populacija u naselju. (...) Jezik i njegovo učenje to je jedan od najvažnijih faktora za očuvanje manjinskog identiteta. U nastavi češkog jezika, plan i program sam prilagodila znanju, sposobnostima te interesima učenika. Smatram nužnim animirati djecu za učenje manjin- 
skog jezika, uvažavajući njihove sposobnosti i interese. (...) Djeca su motivirana, posebice ako se nastava provodi kroz igru, pjesmu ili glumu." (nastavnica, OŠ Vilima Korajca, Kaptol, C model, Česi). Češki jezik sve se slabije koristi u obiteljima Čeha, nacionalno mješovitim ili onima koje su češkog porijekla. Škola je stoga važan prostor u kojemu se jezik afirmira i prenosi na mlađe generacije, a igra i različite sekcije, prema mišljenju nastavnice, najbolji su način edukacije. „Nastavnicima je omogućeno stručno usavršavanje, iako smo to do sada uglavnom zbog obiteljske ograničenosti prilično rijetko koristile takve prilike jer su stručna usavršavanja uglavnom izvan naše županije pa je to teško uskladiti s ostalim obvezama." (učiteljica, roditelj, Česi, OŠ Vilima Korajca, Kaptol). Usavršavanje nastavnika provodi se s nekim poteškoćama koje se odnose prije svega na materijalni položaj nastavnika. „Smatram da dok postoji zainteresiranih učenika da do tada ovaj tip obrazovanja ima perspektivu, iako gledajući dugoročno perspektiva je sve lošija jer učenici se sve manje osjećaju kao pripadnici nacionalne manjine, također radije ranije odlaze kući nego da ostaju na još jednom ili dva školska sata ili odabiru razne sportske aktivnosti umjesto jezika. Interes kod mladih ljudi za očuvanjem kulture i kulturnog identiteta također slabi pa većinom na kulturnim događajima sudjeluju pripadnici zrelog ili starog stanovništva." (učiteljica češkog jezika, Pakrac). Problem mladih i njihovih motiva za sudjelovanje u nacionalnomanjinskim ritualima sve je veći i traži kako teorijsko objašnjenje tako i operativna rješenja na makrorazini i u lokalnim zajednicama. „Djeca su motivirana ako nastava kao takva ne stvara neko posebno dodatno opterećenje za njih jer se češki jezik, bar kod nas održava uglavnom zadnje sate, kada su učenici već veoma umorni i teže im se skoncentrirati. Motivacija se podiže ako se u program uključuju metode i oblici rada koji će naglasiti njihove sposobnosti (npr. učenje jezika kroz pjesmu, glumu i sl.)." (učiteljica, roditelj, Česi, OŠ Vilima Korajca, Kaptol). Kako je sa slovačkim jezikom i kadrovskim problemima/rješenjima u nastavi jezika i kulture te nacionalne zajednice? „Nastavnici slovačkog jezika imaju omogućeno stručno usavršavanje tri puta godišnje u Slovačkoj. Svaki nastavnik izabire na koje usavršavanje želi ići. Također, nastavnici slovačkog jezika redovito imaju Aktive. Što se tiče napredovanja u zvanju, ta mogućnost postoji za slovački jezik, ali je teško izvediva." (nastavnica, Ana Marinac, OŠ Vilima Korajca, Kaptol, Česi). Postoji organizirana edukacija za učitelje, u Hrvatskoj i u Slovačkoj, a napredovanje samo formalno egzistira, dok je u zbilji teže izvedivo. „Učiteljica je išla na porodiljski, ovu drugu baš ne vole... lakrdija, obradili su dve pjesme, ova što sada predaje je nastavnica hrvatskog jezika... Moje dijete gubi volju za tim, ide na robotiku... da je nastavnica prethodna ostala, bilo bi ok. Uče kulturu Srbije, to su učili, ovaj što im predaje je Hrvat po nacionalnosti pa ih ne uči dovoljno. Mali je broj upisa, sve je manje djece... naročito iz Slavonije ljudi odlaze, treba smanjiti prag za ove modele kod nacionalnih manjina... kadrovski problem, nema učitelja.“ (vijećnica grada Pa- 
kraca, roditelj, Srbi, Šeovica). Za učenje jezika i kulture nacionalnih manjina, prema iskazu vijećnice iz redova srpske zajednice, važna je i pripadnost nastavnika toj zajednici. Pitanje edukacije nije u tom području samo obrazovnog nego i emotivnog značenja. Uz to, neka rješenja iz postojećih zakona trebalo bi preispitati, osobito $\mathrm{s}$ obzirom na demografsko starenje populacije u Slavoniji, što je, kao posljedica rata, najprisutnije kod srpske nacionalne manjine. Sudionici fokus-grupe navode više motiva kod učenika za pohađanje nastave u $\mathrm{C}$ modelu za nacionalne manjine. Česi ističu da su, osim motiva za očuvanjem nacionalnog identiteta ili pozivanja na etničko porijeklo, kod učenika važni prijatelji i utjecaj socijalne okoline, ocjene te izleti koje organizira Češka beseda. Srbi navode kao problem malo učenika, što otežava organizaciju nastave, zatim kadrovske probleme i nedostatak udžbenika. Slovaci navode da nastavnici imaju stručno usavršavanje tri puta godišnje. Kao probleme sudionici još navode zadnje sate u kojima se održava nastava za pripadnike nacionalnih manjina, a to je onda kada su učenici već umorni, kao i to da se učenici sve manje, uslijed asimilacije, osjećaju kao pripadnici nacionalne manjine. Kao prednost u nastavi toga tipa ističe se nastava u obliku igre, što učenici najbolje prihvaćaju.

\subsection{Nacionalnomanjinski identiteti: izazovi i perspektiva}

Očuvanje nacionalnog identiteta prioritet je svake nacionalne zajednice, a kod nacionalnih manjina to je često i pitanje opstanka i učinkovit način za usporavanje asimilacije. Situacija je po tom pitanju specifična za svaku etničku/nacionalnu manjinu, ovisno o broju i udjelu zajednice u populaciji kako na razini Hrvatske tako u lokalnim i regionalnim destinacijama, pa do povijesnog naslijeđa, organiziranosti samih zajednica, njihove političke predstavljenosti, povezanosti s matičnom državom/ nacijom i drugim činiteljima i/ili okolnostima. Pitanja koja se odnose na primarnu i sekundarnu socijalizaciju mladih pripadnika nacionalnih manjina imaju posebno značenje za očuvanje identiteta nacionalnih manjina. Stoga je najveći izazov za nacionalne manjine njihov opstanak i ako već ne zaustavljanje procesa asimilacije (što je poželjno, ali teško u potpunosti ostvarivo), barem njezino usporavanje i svođenje na brojčani minimum. Koji su najvažniji izazovi u percepciji sudionika fokus-grupe u Požeško-slavonskoj županiji i kakva je perspektiva pojedinih nacionalnomanjinskih identiteta? „Smatram da je učenje bilo kojeg jezika važno za stjecanje opće kulture i rušenje predrasuda i za obogaćivanje osobnosti djeteta ili odrasle osobe. Ako je cilj očuvanje nacionalnog manjinskog identiteta naravno da je važno učenje manjinskog jezika, kako u školi tako i u drugim oblicima (npr. tečajevima u sklopu udruga i sl.)... Koliko ja znam nema... malo... možda poneka fraza pozdrav i slično povremeno... više iz šale. No postoje još poneke starije osobe koje kada imaju priliku veoma rado govore češki." (učiteljica, roditelj, Česi, OŠ Vilima Korajca, Kaptol). I $\mathrm{u}$ tom istupu potvrđuje se važnost jezika za nacionalni identitet, od učenja u školi 
do nekih drugih oblika. „Pokrenuo sam u Jakšićkoj školi slovački jezik, poznavanje slovačkog. Za učenje slovačkog jezika postoji više razloga, od pripadnosti slovačkoj zajednici, mješoviti brakovi, znatiželja, pragmatični razlozi (zapošljavanje, školovanje). U selu Kneževac govore slovački, djeca znaju čitati slovački. Pjesme se vežu za slovački jezik. Kroz pjesme se lakše uči, znaju oko 50 pjesama. Slovačka država šalje učenike, ljetni tabori ... problem školstva, učitelj u srednjoj ne može skupiti 7 učenika za C model. Udžbenik mora proći postotak onih koji su za njega, mora ih biti $20 \%$ od ukupnog broja učenika." (profesor, predsjednik Matice slovačke Jakšić). Slovački jezik uči se u školi, a u nekim selima gdje živi veći broj Slovaka i gdje je veći udio Slovaka govori se slovački jezik u svakodnevnoj komunikaciji. Važna je i pomoć Slovačke u očuvanju i prijenosu nacionalnog identiteta Slovaka u Požeštini. „U našoj školi su grupe učenika (bar što se tiče učenika od 5. do 8. razreda) veoma mješovite što se tiče znanja... tako da pristup takvoj nastavi mora biti individualiziran, prilagođen, te se plan i program koji je dan koristi samo kao okvirni. Mislim da je nužno sadržaje prilagoditi svakoj pojedinoj školi i interesima učenika na tom području." (učiteljica, roditelj, Česi, OŠ Vilima Korajca, Kaptol). Nastavni plan i program unificirani je dokument, a učenici imaju različito znanje jezika i nacionalne kulture, pa se od nastavnika zahtijeva fleksibilan pristup i što je moguće više individualiziran. „Postignut je uspjeh u učenju ćirilice... Druga djeca se interesiraju za učenje ćirilice. Vijeće osigurava novac za igraonicu, radionicu je održavala žena katolkinja. Djeca su kroz igru naučila dosta toga, sredstava baš i nema, nemamo kontinuitet $\mathrm{u}$ radu igraonica. Na Viru postoji ljetna škola srpskog jezika, kroz radionice, imaju priliku da nauče srpski jezik, jedan od boljih načina... država financira, roditelje se pita. Ima roditelja koji ne žele da im se dijete odvoji od njih, naša djeca su jako loši plivači... mali broj djece ide u ljetne škole.“ (vijećnica grada Pakraca, roditelj, Srbi, Šeovica). Za srpsku nacionalnu manjinu pitanje učenja ćirilice važno je pitanje nacionalnog identiteta. U tom segmentu obrazovanja ima interesa učenika, ali i uspjeha u radu, što indicira dobar smjer u rješavanju te problematike. Tome se mogu pridodati i drugi oblici nastave za nacionalne manjine, poput ljetnih škola, seminara, radionica. Za perspektivu i opstojnost nacionalnomanjinskih zajednica jezik te njegovo očuvanje i promicanje imaju posebnu vrijednost, što ističu i sudionici fokus-grupe. Osim identitetske i simbolične vrijednosti, za jezik i motivaciju učenika važni su još i njegova edukativna i utilitarna dimenzija. Znanje jezika kulturni je kapital u globaliziranom društvu sve otvorenijih granica, a uz tu općekulturnu dimenziju, jezik ima i utilitarnu mogućnost zapošljavanja i studiranja u državama gdje se ti jezici koriste u javnoj i službenoj upotrebi. U životu i obrazovanju pripadnika nacionalnih manjina važni su još i povezivanje sa sunarodnjacima, ljetne i zimske škole, seminari i posjeti inozemnim destinacijama u kojima se govori jezik koji pripadnici nacionalnih manjina uče u školskim programima i u primarnoj socijalnoj sferi. 


\section{Zaključna razmatranja}

Kakva su iskustva u osnovnoškolskom obrazovanju nacionalnih manjina u Požeško-slavonskoj županiji i što o tome kažu sami akteri, u ovom slučaju sudionici fokus-grupe (nastavnici, roditelji, predstavnici lokalne/regionalne zajednice)? Socijalna interakcija i međusobna komunikacija pripadnika različitih etničkih/nacionalnih zajednica, posebno u relaciji s nacionalnom većinom, presudni su za integraciju svih aktera u zajednicu/društvo, a lokalna zajednica pritom je paradigmatski primjer za navedeno. Socijalni obrasci takvih zajednica, kao što su susjedstvo, prijateljstvo, bračni odnosi, generacijske veze, kumstva i slično, indikatori su uspješnosti multietničke koegzistencije (suživota) pripadnika različitih nacionalnih zajednica. U Požeško-slavonskoj županiji, prema nalazima provedene fokus-grupe, prisutna je relativno kvalitetna socijalna interakcija svih aktera, s nekim specifičnostima i problemima koji su dosta različiti od zajednice do zajednice. Predrasude, stereotipi i stigme prisutni su u svim društvima, ali nakon turbulentnih ratnih 90-ih godina 20. stoljeća u Hrvatskoj i u vremenu njezina osamostaljenja kao države ti sociopsihološki obrasci znatno su frekventniji i intenzivniji u odnosu na neka prethodna razdoblja, pogotovo u odnosu na situaciju u socijalističkom poretku. Uslijed strukturalnih društvenih i političkih promjena nacionalna homogenizacija destruirala je dotadašnji obrazac međunacionalnih odnosa i donekle kontroliranog suživota. Česi u ovom istraživanju ukazuju na kvalitetnu integraciju pripadnika te nacionalne zajednice u lokalne zajednice županije i u hrvatsko društvo u cjelini. Predrasude su prisutne i u odnosu prema njima, ali u benignom izdanju, koje se ne pretvara u stigmu s potencijalno opasnim nabojem. Situacija je drugačija u korpusu srpske nacionalne manjine. Njezini predstavnici ističu primjere korektnih odnosa na razini pojedinačnih interakcija, ali problem je percepcija Srba kroz prizmu rata, što rezultira stigmom cjelokupne zajednice, neovisno o ponašanju pojedinaca i njihova odnosa prema hrvatskoj državi. Problem stigme jest u generaliziranju koje ne razlikuje pojedince unutar zajednice, a pritom dugotrajnije egzistiranje stigme pretvara pojedince iz stigmatizirane skupine u metu napada s pozicija moći, od verbalnih do prijetećih i, u konačnici, fizičkih nasrtaja na stigmatizirane. Slovaci navode da je odnos prema njima bolji nego prije, ali ističu i konstantu, a to je percepcija manjina kao svojevrsnog tereta za većinu, što rezultira opterećenjima kod pripadnika manjina, u ovom slučaju nacionalnih. Sudionici fokus-grupe ističu važnost različitih manifestacija važnih za obrazovanje nacionalnih manjina, uključujući i korištenje A, B i C modela obrazovanja. Tu su veze s državom maticom, izleti, kulturne manifestacije, a sve to potiče i motivira učenike iz nacionalnomanjinskog korpusa ili one koji vuku porijeklo iz tih zajednica, pa čak i njihovih prijatelja koji pohađaju obrazovanje na jeziku i pismu nacionalnih manjina. Sudionici Srbi ističu problem malog broja učenika, što je povezano s demografskom devastacijom naselja koja su prije rata bila naseljena 
Srbima te ukupnom pozicijom Slavonije u poslijeratnom razdoblju. Uz to, problem su i kadrovi, pa u nekim slučajevima srpski jezik i kulturu predaju osobe koje, prema njihovim iskazima, nisu dovoljno motivirane za takav oblik nastave. Asimilacija čini svoje, tako da slabi interes za nacionalnomanjinske programe i edukaciju. Ponuda sadržaja treba biti raznolika, a učenicima prezentirana kroz igru, što povećava njihovu motivaciju. Uz to, sve veće otvaranje prema inozemstvu, ulazak Hrvatske u Europsku uniju, mogućnost studentske razmjene i rada u inozemstvu na utilitarnoj razini čini privlačnim nacionalnomanjinsko obrazovanje. Kao primjer stručnog usavršavanja Slovaci navode odlazak svojih nastavnika u Slovačku u okviru stručnog usavršavanja. Izazovi su za nacionalne manjine veliki, posebno kod najmlađih pripadnika te populacije. Situacija je različita kod pojedinih nacionalnih manjina, a najveći su izazovi pred hrvatskim vlastima i srpskom nacionalnom manjinom, čiji su pripadnici pod opterećenjem ratnih događanja i stigme koja se uglavnom povezuje s tim razdobljem, a generira se i na one koji su rođeni nakon završetka ratnih sukoba. Česi i Slovaci integrirani su u lokalne zajednice s kvalitetnim suživotom koji prakticiraju kako s hrvatskom etničkom većinom tako i s pripadnicima drugih nacionalnih zajednica i svim ostalim građanima. Njihov je prioritet očuvanje nacionalnomanjinskog identiteta i sprečavanje ili barem usporavanje asimilacije.

\section{Literatura}

\section{Knjige i časopisi}

Abercrombie, Nicholas, Hill, Stephen, Turner, S. Bryan (2008). Rječnik sociologije. Zagreb: Naklada Jesenski i Turk (urednici hrvatskog izdanja: Jadranka Čačić-Kumpes i Josip Kumpes).

Barry, Brian (2006). Kultura i jednakost: egalitarna kritika multikulturalizma. Zagreb: Naklada Jesenski i Turk.

Feinberg, Walter (2012). Zajedničke škole/različiti identiteti. Nacionalno jedinstvo i kulturna razlika. Beograd: Fabrika knjiga.

Heršak, Emil (ur.). (1998). Leksikon migracijskoga i etničkoga nazivlja. Zagreb: Institut za migracije i narodnosti.

Katunarić, Vjeran (1991). „Jedan uvod u interkulturalizam“, Zagreb, Thélème, god. 37 , br. 2, str. 111-132.

Katunarić, Vjeran (2007). Lica kulture. Zagreb: Antibarbarus.

Kecmanović, Dušan (2001). Etnička vremena. Beograd: Biblioteka XX vek: Čigoja štampa. Knjižara Krug.

Kymlicka, Will (2003). Multikulturalno građanstvo. Zagreb: Naklada Jesenski i Turk. Mesić, Milan (2007). Metodološki kozmopolitizam versus metodološki nacionalizam.

Revija za sociologiju, Vol. 38, No 1-2. 
Mesić, Milan (2012). „Je li (njemački) multikulturalizam mrtav?“ u: Aporije multikulturalizma (priredili: Alpar Lošonc i Dragan Prole). Novi Sad: Centar za multikulturalnost.

Rizman, Rudi (2014). Globalizacija i autonomija. Doprinosi sociologiji globalizacije. Univerza u Ljubljani, Filozofska fakulteta. Zagreb: Politička kultura.

Roth, Klaus (2000). Slike u glavama: ogledi o narodnoj kulturi u jugoistočnoj Europi. Zemun: Biblioteka XX vek; Beograd: Čigoja štampa.

Sand, Shlomo (2012). Kada i kako je izmišljen židovski narod? Zagreb: MISL.

Skoko, Božo, Benković, Vanesa (2009). „Znanstvena metoda fokus grupa - mogućnosti i načini primjene". Zagreb: Politička misao, god. 46, br. 3, str. 217-236.

Smith, D. Anthony (1996/1997). „U odbranu nacije“ u: Nacije/Nation. Beograd: Beogradski krug (ur. Obrad Savić), str. 11-33.

Tamir, Jael (2002). Liberalni nacionalizam. Beograd: Filip Višnjić.

Taylor, Charles (1996/1997). „Nacionalizam i modernost“ u: Nacije/Nation. Beograd: Beogradski krug (ur. Obrad Savić), str. 11-33.

Vlaisavljević, Ugo (2018). Aporije suživota. Ka etnologiji bliskih stranaca. Mostar-Sarajevo-Zagreb: Sveučilište u Mostaru. Synopsis d.o.o. Sarajevo. Synopsis d.o.o. Zagreb.

\section{Izvori}

Izvješće: Odgoj i obrazovanje na jeziku i pismu nacionalnih manjina u školskoj godini 2012./2013. i 2013./2014. Zagreb: Ured za ljudska prava i prava nacionalnih manjina, srpanj 2014.

Popis stanovništva 1991., Dokumentacija 889. Zagreb: Državni zavod za statistiku, 1996.

Popis stanovništva 2001. Zagreb: Državni zavod za statistiku, 2002.

Popis stanovništva 2011., Zagreb: www. Državni zavod za statistiku, 2013.

Ustav RH, Narodne novine, br. 76, Zagreb, 2010.

Ustavni zakon o pravima nacionalnih manjina, Zagreb, 2002.

Zakon o uporabi jezika i pisma nacionalnih manjina u Republici Hrvatskoj. Zagreb, 2000.

Zakon o odgoju i obrazovanju na jeziku i pismu nacionalnih manjina. Zagreb, 2000. 
Radovi Zavoda za znanstveni i umjetnički rad u Požegi, 9 (2020), str. 163-184

D. Babić: Osnovno školstvo nacionalnih manjina u Požeško-slavonskoj županiji (fokus-grupa)

\title{
The System of Primary Education for National Minorities in the Požega-Slavonia County (Focus Group)
}

\section{Summary}

Education at all levels exercises major, perhaps even essential influence not only on the family, but also on the transfer and further development of national identity both in case of the majority national community and of the national/ethnic minorities. In this paper, the author analyses the system of primary education for national minorities in the Požega-Slavonia County. An empirical study has been conducted by using the focus group method on a population sample including various participants - both in the educational system and within the political and social logistic backup thereof (teachers, parents, politicians). E-teaching (C model) in the Požega-Slavonia County has been organized in the Czech, Serbian and Slovak languages. The focus group consequently included members of these national communities. The objective of the empirical study was to perceive the points of view and opinions of the participants in the system of primary education for national minorities, in particular with regard to the communication within the national community and with members of other national communities. Stereotypes, prejudices and stigmas that exist in various periods and localities present a serious problem in communication. The situation becomes intensified in case of the occurrence of turbulent events in the society - such as was the war that took place in the 1990s in the territory of former Yugoslavia, including Croatia. Relationships among members of multinational local communities form a basis and the main social resource of the integration of all the participants both in the community and in the society. Regarding its normative and content-related aspects, the education of national minorities is a significant segment of the preservation, transfer and social construction of the identity of national minorities. The objective of the study was hence to perceive the observations of the participants in the system of primary education for national minorities - the things they regarded as satisfactory, and others they considered in need of improving. In the process of continuous assimilation, and due to the problems related to the integration and the preservation of identity, the participants in the subject process - or rather their points of view and activities - have been of major significance for the existence and perspective of the national minorities they belong to. The objective was to subsume the results of the empirical study and emphasize the fundamental perceptions; this might facilitate finding a solution to this problem topic within the public policies of the Republic of Croatia.

Keywords: national minorities; primary education; the Požega-Slavonia County; the Czechs; the Serbs; the Slovaks.

\author{
Dr. sc. Dragutin Babić \\ Institut za migracije i narodnosti \\ Trg Stjepana Radića 3, 10000 Zagreb \\ dragutin.babic@imin.hr
}

